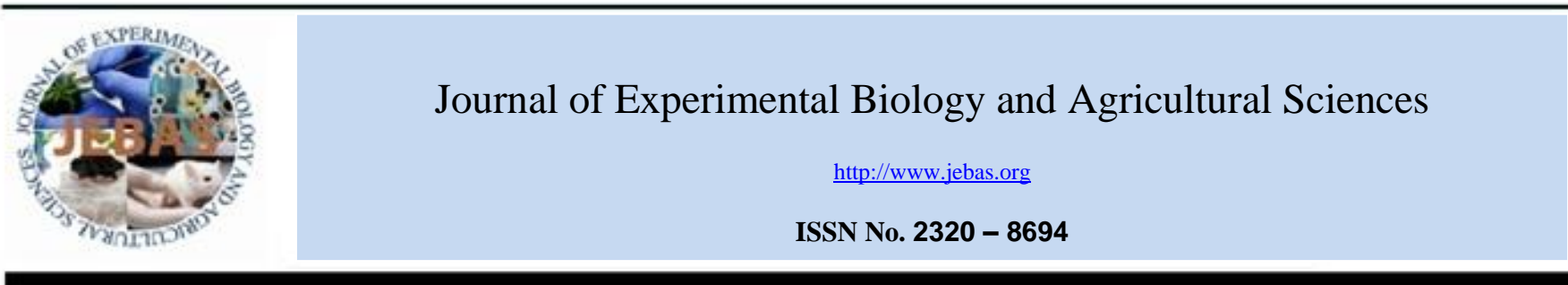

\title{
GENERALIZED URTICARIA AS A VASCULITIC MANIFESTATION IN A PATIENT WITH SARS-CoV-2 INFECTION: A CASE REPORT IN COLOMBIA
}

\author{
Daniela Sepúlveda-Beltran ${ }^{1}(\mathrm{D})$, Alvaro Mondragón-Cardona ${ }^{1,2,3}$ (D), Carlos Enrique Conde- \\ Martin $^{1,2,4}$ (D), Oscar Alberto Lopez-Guevara ${ }^{1,2}$ (D), Nubia Rocio Hernandez-Rojas ${ }^{1,2}$ (D), Mario \\ Alberto Caviedes-Cleves ${ }^{1,2}$ (D), David E. Gutierrez-Ortega ${ }^{1,2}$ (iD), Carmen R. Rangel-Meza ${ }^{1,2}$ (iD), \\ Franci Karina Conde-Tavera $^{1,2}$ (D), Alfonso J. Rodriguez-Morales ${ }^{2,5, *}$ (D), Kuldeep Dhama ${ }^{6}$
}

\footnotetext{
${ }^{1}$ Internal Medicine Department, Sociedad Clínica Emcosalud, Neiva, Huila, Colombia

${ }^{2}$ Latin American Network of Coronavirus Disease 2019 (COVID-19) Research (LANCOVID-19), Pereira, Risaralda, Colombia

${ }^{3}$ Universidad Surcolombiana, Neiva, Huila, Colombia

${ }^{4}$ Infectious Diseases Department, Sociedad Clínica Emcosalud, Neiva, Huila Colombia

${ }^{5}$ Grupo de Investigación Biomedicina, Faculty of Medicine, Fundación Universitaria Autónoma de las Américas, Pereira, Risaralda, Colombia

${ }^{6}$ Division of Pathology, ICAR-Indian Veterinary Research Institute, Izatnagar, Bareilly-243122, Uttar Pradesh, India
}

Received - March 18, 2021; Revision - April 03, 2021; Accepted - April 13, 2021

Available Online - April 25, 2021

DOI: http://dx.doi.org/10.18006/2021.9(2).131.137

KEYWORDS
SARS-CoV2
COVID-19
Autoimmune urticaria
Vasculitis
Colombia

* Corresponding author

E-mail: alfonso.rodriguez@uam.edu.co (Alfonso J. Rodriguez-Morales)

Peer review under responsibility of Journal of Experimental Biology and Agricultural Sciences.

Production and Hosting by Horizon Publisher India [HPI] (http://www.horizonpublisherindia.in/).

All rights reserved.

\begin{abstract}
Skin manifestations have been reported in up to $20 \%$ of cases of SARS-CoV-2 infection, including morbilliform rash (22\%), pernio-like acral lesions (18\%), urticaria (16\%), and macular erythema (13\%). It is believed that in the case of SARS-CoV-2 infection, the mechanism involved is an inflammatory response that generates immune dysregulation, vascular congestion, vasculitis, vascular thrombosis, or neoangiogenesis. This case study, present the case of a patient with no previous history of urticarial reactions, autoimmune diseases, or exposure to medications who develops generalized urticaria lasting more than 24 hours and who was diagnosed with SARS-CoV-2 infection by RT-PCR with a nasopharyngeal swab. We suggest in this patient vasculitic urticaria as a manifestation of SARS-CoV-2 infection.
\end{abstract}

All the articles published by Journal of Experimental Biology and Agricultural Sciences are licensed under a Creative Commons Attribution-NonCommercial 4.0 International License Based on a work at www.jebas.org.

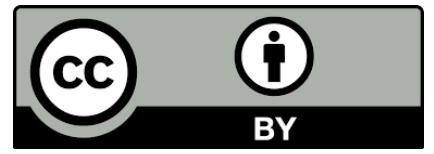




\section{Introduction}

The clinical spectrum of the coronavirus disease 2019 (COVID-19) (Dhama et al., 2020), caused by the severe acute respiratory syndrome-coronavirus-2 (SARS-CoV-2), is still complex (Yuki et al., 2020). This emerging disease, first reported in Wuhan, China (Lu et al., 2020), has extended globally (WHO, 2020) and still produces a vast number of clinical consequences (Ortiz-Maritnez et al., 2020).

Coronaviruses are enveloped, positive-sense, single-stranded RNA viruses that enter the cell through fusion with the receptor for angiotensin-converting enzyme 2 (ACE2), a well-known receptor for SARS-CoV, which is expressed in the cell membrane of numerous organs such as the heart, lung, ileum, central nervous system, kidney, and bladder (Hamming et al., 2004; Zhou et al., 2020). It is suggested that this interaction generates a down regulation of the expression of ACE2, an increase of angiotensin II due to unopposed accumulation, and activation of the reninangiotensin-aldosterone system (RAAS), which altogether play a role in the development of acute respiratory distress syndrome (ARDS) ( Vaduganathan et al., 2020; Zhang et al., 2020a). Furthermore, it contributes to generating endothelial dysfunction, leading to vasoconstriction, increased vascular permeability, and abnormal remodeling of myocardial cells (Vaduganathan et al., 2020).

Transmission occurs mainly via respiratory droplets from direct person-to-person contact and, to a lesser degree, via fomites and aerosols (Wiersinga et al., 2020), with a high rate of spread $\left(\mathrm{R}_{0}\right.$ of 2.24-3.58) reported during the early phase of the outbreak (Chen, 2020; Zhao et al., 2020a). The majority of patients with SARSCoV-2 pneumonia have a good prognosis, and the severity depends primarily on characteristics such as age, comorbidities, and the individual's immune condition (Wang et al., 2020). The gold standard for diagnosis is via viral RNA detection by reverse transcription-polymerase chain reaction (RT-PCR) (Corman et al., 2020; Loeffelholz et al., 2020; Sheikhzadeh et al., 2020). Skin manifestations have been reported in up to $20.4 \%$ of cases of SARS-CoV-2 infection (Recalcati, 2020), with an average onset of 9.92 days following the initiation of systemic symptoms (Zou et al., 2020; Zhao et al., 2020b). The most common manifestations include morbilliform rash (22\%), pernio-like acral lesions (18\%), urticaria (16\%), and macular erythema (13\%) (Freeman et al., 2020).

In SARS-CoV-2 infection, the suggested mechanism involves an inflammatory response that generates immune dysregulation, vascular congestion, vasculitis, vascular thrombosis, or neoangiogenesis. This response can affect the lungs, heart, liver, and kidney; leading to an increase in vascular permeability mediated by mast cell degranulation (Arias-Santiago et al., 2009) and by basophil production of vasoactive amines; and complement activation mediated by circulating immune complexes (Leiste et al., 2008).

\section{Case Report}

A 34-year-old woman with sudden onset of generalized urticaria was predominantly localized to the lower extremities, with subsequent asymmetric, erythematous, round papules (Figure 1); first consulted to the outpatient clinic and was initially managed with antihistamines without clinical improvement. Two days later, she presents to the emergency department, denying any febrile episode since the onset of symptoms, with normal pulse oximeter readings and no respiratory symptoms. During the initial evaluation, a clinical presentation compatible with leukocytoclastic vasculitis was considered. An immunological profile with routine lab tests was requested, which show normal blood count levels, preserved kidney and liver function, CRP of $6.8 \mathrm{mg} / \mathrm{L}$, negative antinuclear antibodies, complement, and IgE within normal limits. Management with corticosteroids is initiated, presenting a slight improvement of the lesions with the pruritus's persistence. Four days later, she starts presenting with dyspnea on exertion, requiring a new visit to the emergency department, where blood tests taken at the moment revealed neutrophilic leukocytosis without any other significant finding. The patient remained afebrile, with adequate oxygen saturation $(95 \%)$ on a $\mathrm{FiO}_{2}$ of $21 \%$, and mild hypoxemia noted on arterial blood gas analysis.

Further testing showed ferritin of $1200 \mathrm{mcg} / \mathrm{L}$ and D-dimer of $6880 \mathrm{mcg} / \mathrm{L}$. Given the presence of hypoxemia, a high-resolution computed tomography (HRCT) of the chest was ordered, which showed a discrete random interstitial compromise with an associated solitary lung nodule of indeterminate appearance localized to the right lower lobe; which, according to the official radiologic report, may correspond to a granuloma of probable residual origin and incipient paraseptal emphysema (Figure 2). Performing an active search for SARS-CoV2, a nasopharyngeal swab for RT-PCR was taken and reported as positive. Three days later, the pruritus and the cutaneous manifestations disappeared with no signs of persistent pulmonary compromise. On the seventh day, follow-up laboratory tests showed acute inflammatory markers within normal limits. On day fourteen, repeat RT-PCR testing for SARS-CoV-2 was reported as negative; the IgM rapid test reported positive with negative IgG. Laboratory findings are found in Table 1

\section{Discussion}

The SARS-CoV-2 infection has become a relevant issue for public health at the moment. The associated cutaneous manifestations have been prevailing as a critical aspect to take into consideration in the clinical course of the disease, although the most frequent 
Table 1 Laboratory findings in the patient with COVID-19

\begin{tabular}{|c|c|c|c|c|c|}
\hline \multirow[b]{2}{*}{ Test } & \multirow[b]{2}{*}{$\begin{array}{c}\text { Normal } \\
\text { values }\end{array}$} & \multicolumn{4}{|c|}{ DATE } \\
\hline & & 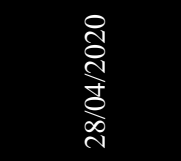 & 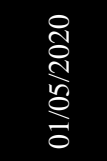 & 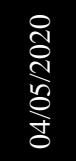 & 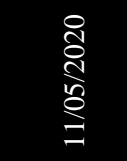 \\
\hline Blood leukocyte count, $10^{\wedge} 9 / \mathrm{L}$ & $3.7-10.1$ & 11.76 & 13.0 & 11.7 & 8.4 \\
\hline Lymphocyte, $\%$ & $18.0-48.3$ & 37.8 & 18.8 & 11.6 & 26.9 \\
\hline Lymphocyte count, $10^{\wedge} 9 / \mathrm{L}$ & $1.09-2.99$ & 4.45 & 2.46 & 2.36 & 2.27 \\
\hline Neutrophil, \% & $39.3-73.7$ & 53.3 & 70.7 & 78.2 & 56.5 \\
\hline Neutrophil count, $10^{\wedge} 9 / \mathrm{L}$ & $1.63-6.96$ & 6.26 & 9.2 & 7.2 & 4.7 \\
\hline Neutrophil to lymphocyte ratio (NLR) & $0.78-3.53$ & 1.40 & 3.79 & 3.05 & 2.07 \\
\hline Monocyte, $\%$ & $0.00-10.0$ & 5.4 & 8.6 & 5.9 & 10.6 \\
\hline Monocyte count, $10^{\wedge} 9 / \mathrm{L}$ & $0.3-0.9$ & 0.64 & 1.13 & 0.69 & 0.89 \\
\hline Eosinophil, \% & $0.00-7.00$ & 2.8 & 0.83 & 3.9 & 4.68 \\
\hline Eosinophil count, $10^{\wedge} 9 / \mathrm{L}$ & $0-0.5$ & 0.33 & 0.105 & 0.46 & 0.36 \\
\hline Basophil, \% & $0.00-1.00$ & 0.5 & 0.9 & 0.4 & 1.20 \\
\hline Basophil count, $10^{\wedge} 9 / \mathrm{L}$ & $0-0.2$ & 0.06 & 0.11 & 0.05 & 0.10 \\
\hline Erythrocyte count, $10^{\wedge} 6 / \mathrm{uL}$ & $4.06-4.69$ & 4.87 & 5.20 & 5.4 & 5.08 \\
\hline Hemoglobin, g/dL & $11.7-18$ & 13.2 & 14.4 & 15 & 14.2 \\
\hline Hematocrit, $\%$ & $37.7-53.7$ & 40.6 & 45.1 & 42.3 & 43.9 \\
\hline Mean cell volume (MCV), fL & $79.0-101.0$ & 83.4 & 86.7 & 88 & 86.3 \\
\hline Mean cell hemoglobin $(\mathrm{MCH}), \mathrm{pg}$ & $26.0-35.0$ & 27.1 & 27.7 & 31.9 & 28 \\
\hline Mean corpuscular hemoglobin concentration (MCHC), g/dL & $31.0-37.0$ & 32.5 & 32.0 & 32 & 32.4 \\
\hline Red blood cell distribution width (RDW), $\mu \mathrm{m}$ & $11.5-14.5$ & 11.9 & 12.1 & 14 & 11.9 \\
\hline Platelet count, $10^{\wedge} 9 / \mathrm{L}$ & $150-450$ & 318 & 317 & 313 & 382 \\
\hline Mean platelet volume, $\mathrm{Fl}$ & $4.5-10$ & 9.9 & 13.0 & 9.3 & 7.36 \\
\hline C-reactive protein level, $\mathrm{mg} / \mathrm{L}$ & $0-5$ & 6.8 & 18 & 12 & 0.0 \\
\hline Ferritin (mcg/L) & $<300$ & - & 1200 & 620 & 215 \\
\hline $\mathrm{D}-\operatorname{dimer}(\mathrm{mcg} / \mathrm{L})$ & $<500$ & - & 6880 & 920 & 440 \\
\hline TSH (mUl/L) & $0.46-4.68$ & 2.5 & - & - & - \\
\hline $\mathrm{T} 4$ (ng/dL) & $0.89-1.76$ & 0.92 & - & - & - \\
\hline T3L $(\mathrm{pg} / \mathrm{dL})$ & $1.8-4.2$ & 4.27 & - & - & - \\
\hline $\mathrm{C} 3$ (ng/dL) & & 117 & - & - & - \\
\hline $\mathrm{C} 4$ (ng/dL) & & 24.1 & - & - & - \\
\hline Eosinophil count & & $3 \%$ & - & - & - \\
\hline E- Inmunoglobulin & $<150 \mathrm{IU} / \mathrm{ml}$ & 50.4 & & & \\
\hline Antibodies Antinuclear & & Non Reactive & - & - & - \\
\hline Antibodies Anti Rnp: & $<20$ & 5.39 & - & - & - \\
\hline Antibodies Anti Smp: & $<20$ & 4.41 & - & - & - \\
\hline Antibodies Anti Ssa (Ro): & $<20$ & 1.96 & - & - & - \\
\hline Antibodies Anti Ssb (La): & $<20$ & 10.53 & - & - & - \\
\hline C-ANCAS PR3 & $>1 / 20$ & Negative & - & - & - \\
\hline P-ANCAS MPO & $>1 / 20$ & Negative & - & - & - \\
\hline \multicolumn{6}{|l|}{ Arterial-blood gases } \\
\hline $\mathrm{pH}$ & $7.36-7.44$ & - & 7.39 & 7.37 & 7.43 \\
\hline $\mathrm{pCO} 2(\mathrm{mmHg})$ & $33-40$ & - & 41 & 41 & 34.6 \\
\hline $\mathrm{pO} 2(\mathrm{mmHg})$ & $70-80$ & - & 66.3 & 70.2 & 83 \\
\hline $\mathrm{HCO} 3(\mathrm{mmol} / \mathrm{L})$ & $21-27$ & - & 21 & 22 & 23 \\
\hline BEb Base Excess (mmol/L) & -3 to +3 & - & 0 & 0 & 0 \\
\hline $\mathrm{SO} 2 \%$ & & - & 97 & 96 & 98 \\
\hline Temperature $\left({ }^{\circ} \mathrm{C}\right)$ & & - & 37.4 & 36.7 & 37.3 \\
\hline $\mathrm{FIO}_{2} \%$ & & - & 21 & 21 & 21 \\
\hline RT - PCR SARS-CoV-2 & & & Positive & & \\
\hline SARS - CoV2 (COVID - 19) Antibodies IgG & & & & & Negative \\
\hline SARS - CoV2 (COVID - 19) Antibodies IgM & & & & & Positive \\
\hline
\end{tabular}




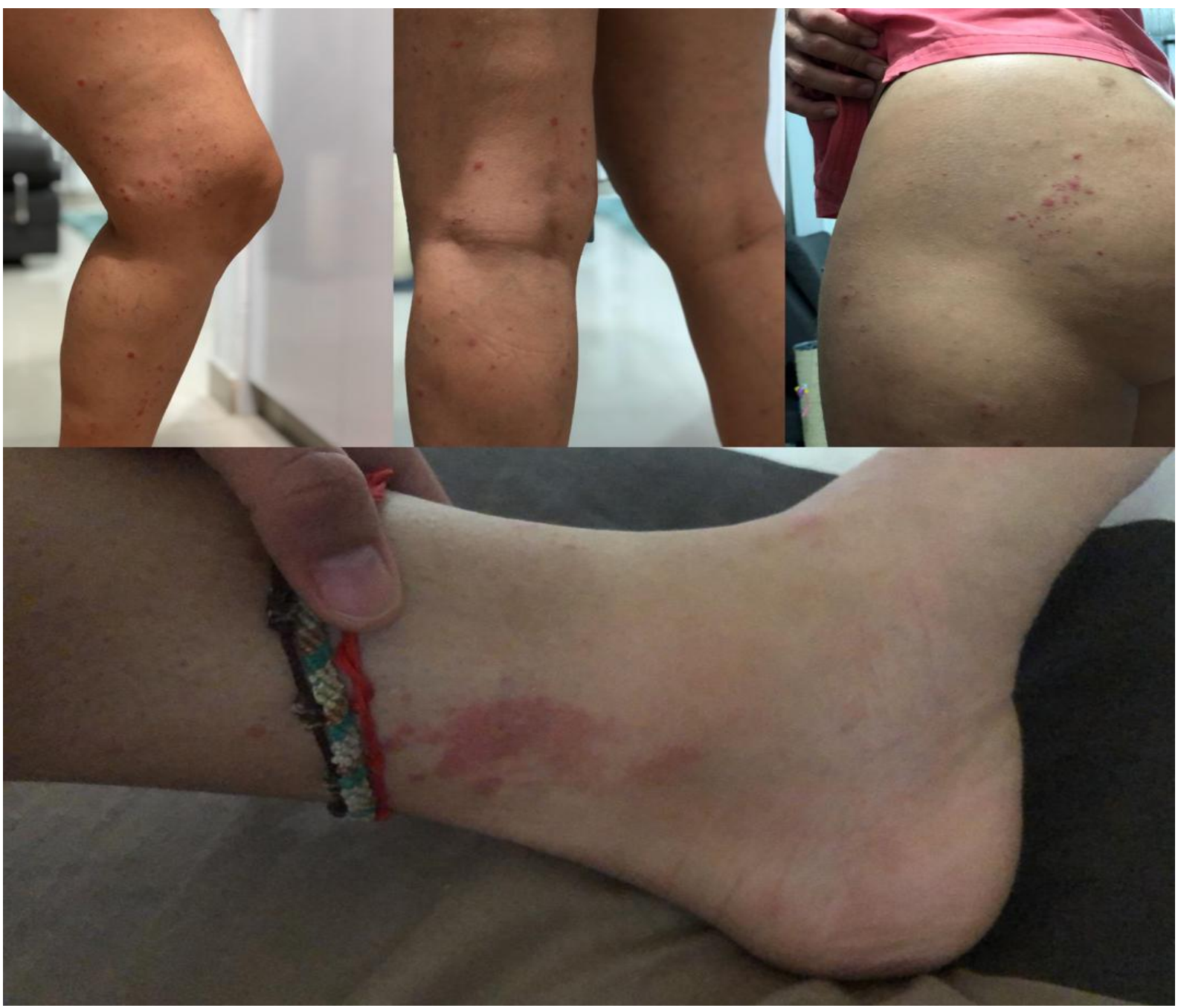

Figure 1 Cutaneous findings in the patient

initial symptoms are fever, fatigue, cough, dyspnea, myalgia, headache, and diarrhea; and to a lesser extent, nasal congestion, runny nose, and odynophagia. In severe cases, dyspnea and hypoxemia rapidly progress to ARDS, septic shock, refractory metabolic acidosis, and multi-organ dysfunction due to gastrointestinal complications, acute heart injury, acute kidney failure coagulopathy (Rossi et al., 2003; Huang et al., 2020). Mortality is mainly dependent on ARDS and its sequelae, along with an exaggerated inflammatory response called a cytokine storm (Zhang et al., 2020b).

Skin manifestations have been reported in up to $20.4 \%$ of cases of SARS-CoV-2 infection (Recalcati, 2020), with an average onset of 9.92 days posterior to the initiation of systemic symptoms (Zhao et al., 2020b). Among these manifestations, the most common include morbilliform rash (22\%), pernio-like acral lesions (18\%), urticaria (16\%), and macular erythema (13\%). Less frequently, vesicular eruption (11\%), papulosquamous eruption (9.9\%), and retiform purpura (6.4\%) (Freeman et al., 2020). Regarding the pathophysiology of SARS-CoV-2 infection, the mechanism involved remains unclear but suggested evidence points toward a possible immune dysregulation, vascular congestion, vasculitis, vascular thrombosis, or neoangiogenesis. All of which have their impact on the lungs, heart, liver, and kidney.

Multiple mechanisms have been proposed as triggers for this type 1 hypersensitivity reaction, most of which lead to increased vascular permeability. Some authors have suggested a crossreaction between $\operatorname{IgM}$ or $\operatorname{IgG}$ antibodies, secondary to the infection, with IgE localized on mast cells' surface, which promotes mast cell degranulation (Arias-Santiago et al., 2009). In contrast, other groups defend that circulating immune complexes stimulate vasoactive amines by basophils and activate complement (Leiste et al., 2008). As a response to viral infection, cells of the 


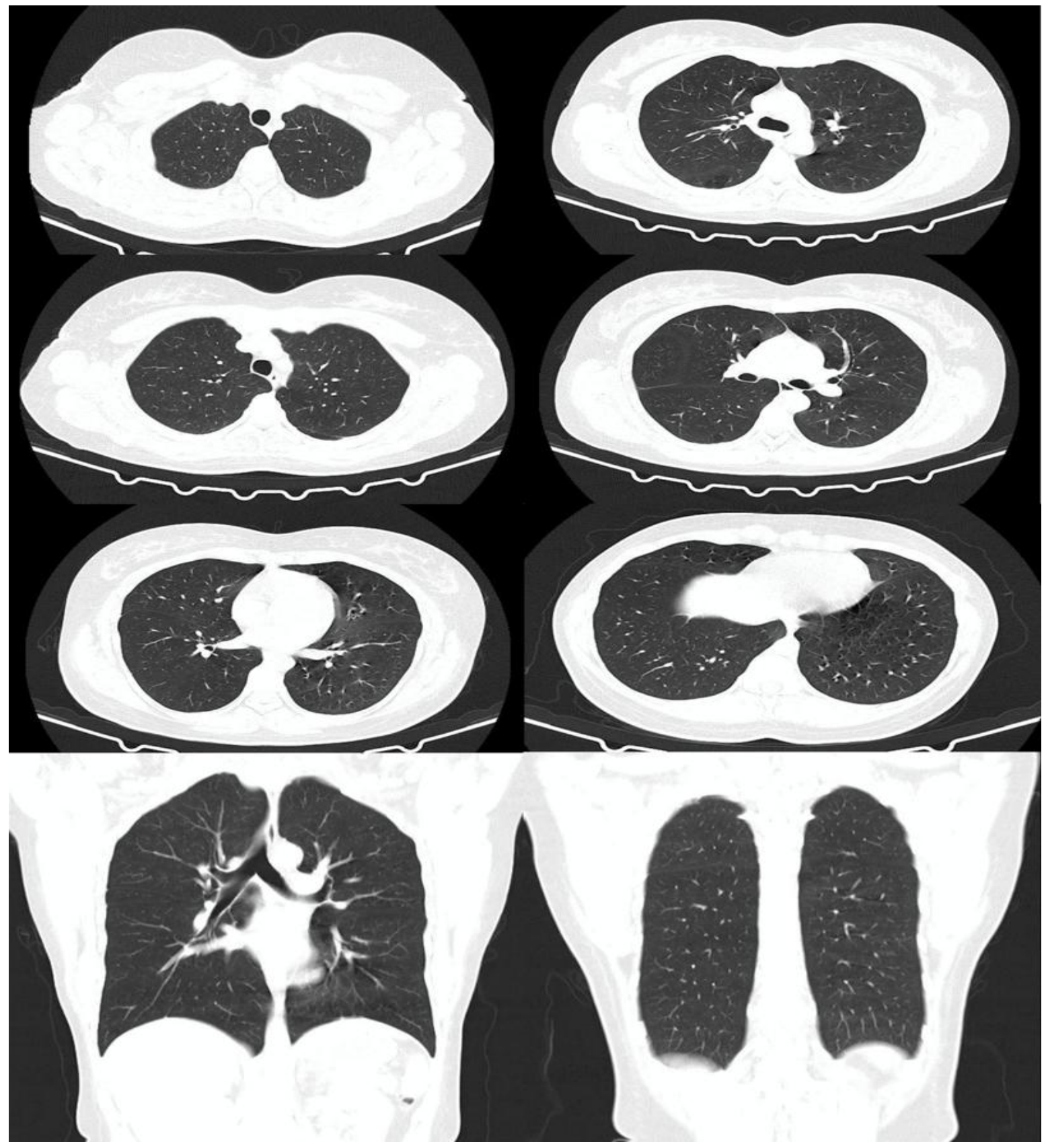

Figure 2 High-resolution computed tomography (HRCT) of the chest

immune system, including mast cells; found in the submucosa of the respiratory tract and the nasal cavity, release a series of inflammatory markers, including protease and cytokines, such as IL-1, IL-6, or IL-33; and histamine (Kritas et al., 2020). Such histamine release triggers the appearance of hives and angioedema. Vasculitic changes in SARS-CoV-2 infections are mainly related to the lymphocyte response and exhibit a few histopathological characteristics, such as dermal edema, vacuolar alteration of the basal layer, keratinocyte necrosis. A mixed infiltrate with a predominant perivascular and peri-eccrine distribution in the papillary (superficial) and reticular (deep) layers of the dermis and the hypodermis (Kolivras et al., 2020; Recalcati et al., 2020; Romaní et al., 2020; ); however, these vasculitic changes may also be related to a pauci-inflammatory thrombogenic vasculopathy in patients with severe SARS-CoV-2 infection due to activation of the complement pathways and an associated procoagulant state (Magro et al., 2020; Zhang et al., 2020c).

Journal of Experimental Biology and Agricultural Sciences http://www.jebas.org 
We present a patient with no previous history of urticarial reactions, autoimmune diseases, or exposure to medications that develops a widespread urticaria lasting more than 24 hours SARS$\mathrm{CoV}-2$ infection is diagnosed employing a nasopharyngeal swab for RT-PCR. Vasculitic urticaria is established as an associated manifestation of SARS-CoV-2 in this patient; therefore, although not frequently documented, we highlight the importance of dermatological findings as possible clinical pictures of the disease; and consequently, we emphasize the need for adequate precautions when evaluating patients who present to the clinical setting with cutaneous symptoms during the pandemic. That could have a significant impact on the prevention of the spread of the infection Only time will elucidate the behavior and implications of these findings.

\section{Author contributions}

All the authors substantially contributed to the conception, compilation of data, checking and approving the final version of the manuscript, and agree to be accountable for its contents.

\section{Acknowledgements}

All the authors acknowledge and thanks their respective Institutes and Universities.

\section{Funding}

None.

\section{Consent for publication}

Written consent from the patient was obtained for publication.

\section{Competing interests}

The authors declare that they have no competing interests.

\section{References}

Arias-Santiago SA, Almazán-Fernández FM, Burkhardt-Pérez P, Naranjo-Sintes R (2009) Urticaria a frigore asociada a mononucleosis por virus de Epstein-Barr. Actas DermoSifiliográficas 100(5): 435-436. https://doi.org/10.1016/s0001 7310(09)71265-7.

Chen J (2020) Pathogenicity and transmissibility of 2019-nCoVA quick overview and comparison with other emerging viruses. Microbes and Infection 22(2): 69-71. https://doi.org/10.1016/j.micinf.2020.01.004.

Corman VM, Landt O, Kaiser M, Molenkamp R, Meijer A, Chu DK, Bleicker T, Brünink S, Schneider J, Schmidt ML, Mulders DG, Haagmans BL, van der Veer B, et al. (2020) Detection of
2019 novel coronavirus (2019-nCoV) by real-time RT-PCR. Euro surveillance : bulletin Europeen sur les maladies transmissibles = European communicable disease bulletin 25(3):2000045. https://doi.org/10.2807/1560-7917.ES.2020.25.3.2000045.

Dhama K, Khan S, Tiwari R, Sircar S, Bhat S, Malik YS, Singh KP, Chaicumpa W, Bonilla-Aldana DK, Rodriguez-Morales AJ (2020) Coronavirus Disease 2019-COVID-19. Clinical Microbiology Reviews 33(4):e00028-20.

Freeman EE, McMahon DE, Lipoff JB, Rosenbach M, Kovarik C, Desai SR, Fox LP (2020) The spectrum of COVID-19-associated dermatologic manifestations: an international registry of 716 patients from 31 countries. Journal of the American Academy of Dermatology. https://doi.org/10.1016/j.jaad.2020.06.1016.

Hamming I, Timens W, Bulthuis M, Lely A, Navis G, Goor HV (2004) Tissue distribution of ACE2 protein, the functional receptor for SARS coronavirus. A first step in understanding SARS pathogenesis. The Journal of Pathology 203(2): 631-637. https://doi.org/10.1002/path.1570.

Huang C, Wang Y, Li X, Ren L, Zhao J, Hu Y, Cao B (2020) Clinical features of patients infected with 2019 novel coronavirus in Wuhan, China. The Lancet 395(10223): 497-506. https://doi.org/10.1016/s0140-6736(20)30183-5.

Kolivras A, Dehavay F, Delplace D, Feoli F, Meiers I, Milone L, Olemans C, Sass U, Theunis A, Thompson CT, Van De Borne L, Richert B (2020) Coronavirus (COVID-19) infection-induced chilblains: A case report with histopathologic findings. JAAD case reports, 6(6): 489-492. Advance online publication. https://doi.org/10.1016/j.jdcr.2020.04.011.

Kritas SK, Ronconi G, Caraffa A, Gallenga CE, Ross R, Conti P (2020) Mast cells contribute to coronavirus-induced inflammation: new anti-inflammatory strategy. Journal of Biological Regulators and Homeostatic Agents 34(1): 9-14. https://doi.org/10.23812/20Editorial-Kritas.

Leiste A, Skaletz-Rorowski A, Venten I, Altmeyer P, Brockmeyer NH (2008) Urticaria associated with Norovirus infection: Report of two cases. Journal Der Deutschen Dermatologischen Gesellschaft 6(7): 563-565. https://doi.org/10.1111/j.1610-0387.2007.06501.x.

Loeffelholz MJ, Tang YW (2020) Laboratory diagnosis of emerging human coronavirus infections - the state of the art. Emerging microbes \& infections 9(1): 747-756. https://doi.org/10.1080/22221751.2020.1745095.

Lu H, Stratton CW, Tang Y (2020) Outbreak of pneumonia of unknown etiology in Wuhan, China: The mystery and the miracle. 


Journal of Medical Virology 92(4): 401-402.

doi:10.1002/jmv.25678.

Magro C, Mulvey JJ, Berlin D, Nuovo G, Salvatore S, Harp J, Baxter-Stoltzfus A, Laurence J (2020) Complement associated microvascular injury and thrombosis in the pathogenesis of severe COVID-19 infection: A report of five cases. Translational research : the journal of laboratory and clinical medicine 220: 1-13. https://doi.org/10.1016/j.trsl.2020.04.007.

Ortiz-Martínez Y, Cabeza-Ruiz LD, Vásquez-Lozano SH, Villamil-Gómez WE, Rodriguez-Morales AJ (2020) Pericarditis in a young internal medicine resident with COVID-19 in Colombia. Travel medicine and infectious disease 37: 101863. https://doi.org/10.1016/j.tmaid.2020.101863.

Recalcati S (2020) Cutaneous manifestations in COVID-19: a first perspective. Journal of the European Academy of Dermatology and Venereology : Journal of the European Academy of Dermatology and Venereology 34(5): e212-e213. https://doi.org/10.1111/jdv.16387.

Recalcati S, Barbagallo T, Frasin L, Prestinari F, Cogliardi A, Provero M, Fantini F (2020) Acral cutaneous lesions in the time of COVID-19. Journal of the European Academy of Dermatology and Venereology 34(8): 346-347. https://doi.org/10.1111/jdv.16533.

Romaní J, Baselga E, Mitjà O, Riera-Martí N, Garbayo P, Vicente A, Calzado S (2020) Lesiones pernióticas y acrales en España durante el confinamiento por COVID: análisis retrospectivo de 12 casos. Actas Dermo-Sifiliográficas 111(5): 426-429. https://doi.org/10.1016/j.ad.2020.04.002.

Rossi SE, Erasmus JJ, Volpacchio M, Franquet T, Castiglioni T, Mcadams HP (2003) "Crazy-Paving" Pattern at Thin-Section CT of the Lungs: Radiologic-Pathologic Overview. RadioGraphics 23(6): 1509-1519. https://doi.org/10.1148/rg.236035101.

Sheikhzadeh E, Eissa S, Ismail A, Zourob M (2020) Diagnostic techniques for COVID-19 and new developments. Talanta 220: 121392. https://doi.org/10.1016/j.talanta.2020.121392.

Vaduganathan M, Vardeny O, Michel T, McMurray JJV, Pfeffer MA, Solomon SD (2020) Renin-Angiotensin-Aldosterone System Inhibitors in Patients with Covid-19. New England Journal of Medicine $\quad 382(17)$ : $1653-1659$. https://doi.org/10.1056/nejmsr2005760.

Wang W, Tang J, Wei F (2020) Updated understanding of the outbreak of 2019 novel coronavirus (2019-nCoV) in Wuhan, China. Journal of medical virology 92(4): 441-447. https://doi.org/10.1002/jmv.25689.

Wiersinga WJ, Rhodes A, Cheng AC, Peacock SJ, Prescott HC (2020) Pathophysiology, Transmission, Diagnosis, and Treatment of Coronavirus Disease 2019 (COVID-19). Journal of the American Medical Association "JAMA" 324(8):782-793. doi:10.1001/jama.2020.12839.

World Health Organization (2020) Coronavirus Disease 2019 (COVID-19) Situation Report - 51

Yuki K, Fujiogi M, Koutsogiannaki S (2020). COVID-19 pathophysiology: A review. Clinical Immunology 215: 108427. doi:10.1016/j.clim.2020.108427.

Zhang C, Wu Z, Li JW, Zhao H, Wang GQ (2020b) Cytokine release syndrome in severe COVID-19: interleukin-6 receptor antagonist tocilizumab may be the key to reduce mortality. International Journal of Antimicrobial Agents 55(5): 105954. https://doi.org/10.1016/j.ijantimicag.2020.105954.

Zhang X, Li S, Niu S (2020a) ACE2 and COVID-19 and the resulting ARDS. Postgraduate Medical Journal 96(1137): 403-407. https://doi.org/10.1136/postgradmedj-2020-137935.

Zhang Y, Cao W, Xiao M, Li YJ, Yang Y, Zhao J, Zhou X, Jiang W, Zhao YQ, Zhang SY, Li TS (2020c) Zhonghua xue ye xue za zhi = Zhonghua xueyexue zazhi, 41(0): E006. https://doi.org/10.3760/cma.j.issn.0253-2727.2020.0006.

Zhao Q, Fang X, Pang Z, Zhang B, Liu H, Zhang F (2020b) COVID-19 and cutaneous manifestations: A systematic review. Journal of the European Academy of Dermatology and Venereology 34(11):2505-2510. doi: 10.1111/jdv.16778.

Zhao S, Lin Q, Ran J, Musa SS, Yang G, Wang W, Lou Y, Gao D, Yang L, He D, Wang MH (2020a) Preliminary estimation of the basic reproduction number of novel coronavirus (2019-nCoV) in China, from 2019 to 2020: A data-driven analysis in the early phase of the outbreak. International journal of infectious diseases : IJID : official publication of the International Society for Infectious Diseases 214-217. https://doi.org/10.1016/j.ijid.2020.01.050.

Zou X, Chen K, Zou J, Han P, Hao J, Han Z (2020) Single-cell RNA-seq data analysis on the receptor ACE2 expression reveals the potential risk of different human organs vulnerable to 2019nCoV infection. Frontiers of Medicine 14(2): 185-192. https://doi.org/10.1007/s11684-020-0754-0. 